\title{
EXPERIMENTAL MODEL OF C6 BRAIN TUMORS IN ATHYMIC RATS
}

\author{
Flávio K. Miura', Maria José Ferreira Alves², Mussya Cisotto Rocha ${ }^{3}$, Roseli S. Silva ${ }^{3}$, \\ Sueli M. Oba-Shinjo ${ }^{4}$, M. Uno ${ }^{4}$, C. Colin ${ }^{5}$, M.C. Sogayar ${ }^{6}$, Sueli K.N. Marie
}

\begin{abstract}
Malignant brain tumor experimental models tend to employ cells that are immunologically compatible with the receptor animal. In this study, we have proposed an experimental model of encephalic tumor development by injecting C6 cells into athymic Rowett rats, aiming at reaching a model which more closely resembles to the human glioma tumor. In our model, we observed micro-infiltration of tumor cell clusters in the vicinity of the main tumor mass, and of more distal isolated tumor cells immersed in normal encephalic parenchyma. This degree of infiltration is superior to that usually observed in other C6 models.
\end{abstract}

KEY WORDS: brain tumor, C6 cells, experimental model, glioma.

\section{Modelo experimental de tumor cerebral $\mathrm{C} 6 \mathrm{em}$ ratos atímicos}

Resumo - Modelos experimentais de tumores cerebrais malignos geralmente utilizam células imunologicamente compatíveis com o animal receptor. Neste estudo apresentamos um modelo experimental baseado na inoculação de células $\mathrm{C} 6$ em ratos atímicos Rowett, visando obter um tumor que se assemelhe mais àqueles observados nos seres humanos. Neste modelo observamos microinfiltração de ilhotas de células na periferia da massa tumoral principal e nas áreas mais distantes, células tumorais isoladas no tecido cerebral normal. Este grau de infiltração é superior àquele observado em outros modelos utilizando as células C6.

PALAVRAS-CHAVE: tumor cerebral, células C6, modelo experimental, glioma.

The need for therapeutic strategies for gliomas has led to the development of experimental models simulating the growth and invasive characteristics of these tumors. Experimental models tend to employ cells that are immunologically compatible with the receptor animal. One of the most classical multiform glioblastoma models is based on injecting $\mathrm{C} 6$ cells (murine glioma) into Wistar rats.

Recent studies have demonstrated that these cells induce a strong immunological response in Wistar rats which, in turn, may compromise interpretation of the results in therapeutic tests. Another approach is based on using immunosuppressed animals. Immunosupressed (or athymic) rats are necessary when inoculating cell cultures derived from patient's tumors. Other models are either incompatible, or do not reproduce the invasive characteristics of gliomas $^{1-7}$.

The objective of the present work was to present the technique, along with clinical and pathological results, for an experimental glioma model by injecting murine glioma cells (C6) in athymic rats.

\section{METHOD}

Cell culture

C6 murine glioma cells were provided by the Cell and Molecular Therapy Center (NUCEL) of the São Paulo University (USP). Cells were cultured in Dulbecco's modified medium (DMEM, Gibco BRL, Gaithersburg, MD), supplemented with 10\% fetal bovine serum (Cultilab, Campinas, SP, Brazil) and antibiotics (penicillin $200 \mathrm{UI} / \mathrm{mL}$ and streptomycin, $100 \mu \mathrm{g} / \mathrm{mL}$, Invitrogen, USA), in $5 \% \mathrm{CO}_{2}$ atmosphere, at $37^{\circ} \mathrm{C}$. Upon reaching confluence, the cultures were dissociated using trypsin/EDTA 250 mg\% (Cultilab, Campinas, São Paulo) and resuspended in serumfree DMEM. The cells were centrifuged, counted in a Neubauer chamber (Optik Labor, Germany) and suspended at $1 \times 10^{5}$ cells in $4 \mu \mathrm{L}$ of serum-free DMEM.

\footnotetext{
'MD, Ph.D, Department of Neurology, University of São Paulo Medical School, São Paulo, Brazil; ' Undergraduate student, Department of Neurology, University of São Paulo Medical School, São Paulo, Brazil; ${ }^{3}$ Post-graduate student, Department of Neurology, University of São Paulo Medical School, São Paulo, Brazil; ${ }^{4}$ Ph.D, Department of Neurology, University of São Paulo Medical School, São Paulo, Brazil; ${ }^{5}$ Graduate student, Cell and Molecular Therapy Center, University of São Paulo Chemistry Institute, São Paulo, Brazil; ${ }^{6}$ Ph.D, Full Professor, Cell and Molecular Therapy Center, University of São Paulo Chemistry Institute, São Paulo, Brazil; 'MD, Ph.D, Associate Professor, Department of Neurology, São Paulo Medical School, São Paulo, Brazil
}

Received 28 September 2007, received in final form 13 December 2007. Accepted 11 February 2008. 


\section{Subcutaneous innoculation}

Female Rowett rats, ( $n=2)$ weighing $140 \mathrm{~g}$, were provided by the Animal Facility of the University of São Paulo Chemistry Institute. The animals were maintained in cages with individual ventilation systems (Tecniplast, Italy), with free access to water and autoclaved food. All animals were handled in accordance with the guidelines recommended by the USP Medical School's Laboratory Animal Care Committee. Following antisepsis treatment of the skin, using $70 \%$ ethanol, the $\mathrm{C} 6$ cell suspension $\left(1 \times 10^{5}\right.$ cells) in $4 \mu \mathrm{L}$ of serum-free DMEM was inoculated into the right flank of the animals.

The animals were observed daily for 21 days. At the end of this period, the tumor mass of both rats measured $2.5 \mathrm{~cm}$ across their widest diameter. Subsequently, the rats were sacrificed using a ketamine overdose $(25 \mathrm{mg})$ and the tumor mass was surgically extracted using sterile techniques. The weight of the two masses was identical in both rats, namely $3.58 \mathrm{~g}$. These tumor masses were used to generate primary cultures and, repeating the culture process outlined, further aliquots of $1 \times 10^{5} \mathrm{C} 6$ cells in $4 \mu \mathrm{L}$ of serum-free DMEM were prepared.

\section{Intracerebral inoculation}

Five female Rowett rats, weighing an average of 140g provided by the Animal Facility of the USP Chemistry Institute, were anesthetized using ketamine $(90 \mathrm{mg} / \mathrm{kg})$ and positioned in a stereotaxic device for small animals (Kopft, Germany). After antisepsis of the skin covering the cranium using $70 \%$ ethanol, a median incision of approximately $1 \mathrm{~cm}$ was made and access to the cranial cavity was achieved by means of a right frontal trepanation, $2 \mathrm{~mm}$ in front of the coronal suture and $2 \mathrm{~mm}$ to the side of the sagittal suture (standard coordinates for brain tumor models). This procedure was carried out using a mini electric drill (Bosch).

An aliquot $\left(1 \times 10^{5}\right)$ of $C 6$ cells in $4 \mu \mathrm{L}$ of serum-free DMEM was inoculated to a depth of $3 \mathrm{~mm}$ with a $25 \mu \mathrm{L}$ Hamilton syringe using the stereotaxic technique. Inoculation was performed slowly over a 5-minute period. The needle was left in position for 10 minutes to prevent from refluxing along the needle trajectory. After removing the needle, trepanation was occluded using wax for bone (Ethicon), and the skin was sutured using two separate 5-0 mononylon stitches (Ethicon). Following the surgical procedure, the rat was placed back into the cage with free access to water and food.

The rats were examined daily to check for any changes in gait, suggestive of motor deficit, or secretion build-up in the periocular region. Three weeks later, despite slight signs of periocular secretion build-up and no motor deficit symptoms, the rats were sacrificed using a thionembutal overdose. Cardiac perfusion was performed with $100 \mathrm{~mL}$ phosphate buffer saline (PBS) and $80 \mathrm{~mL}$ of $4 \%$ paraformaldehyde, followed by extraction of the brains. The whole brains were fixed in $4 \%$ paraformaldehyde for one week, then sliced in coronal preparations of $1 \mathrm{~cm}$ of thickness, mounted in paraffin blocks, followed by preparation of $5 \mu \mathrm{m}$-thick serial sections. Relevant macroscopical slices of the tumor, together with surrounding cerebral tissue, were mounted on microscope slides and stained with eosin-hematoxylin for histological analysis.

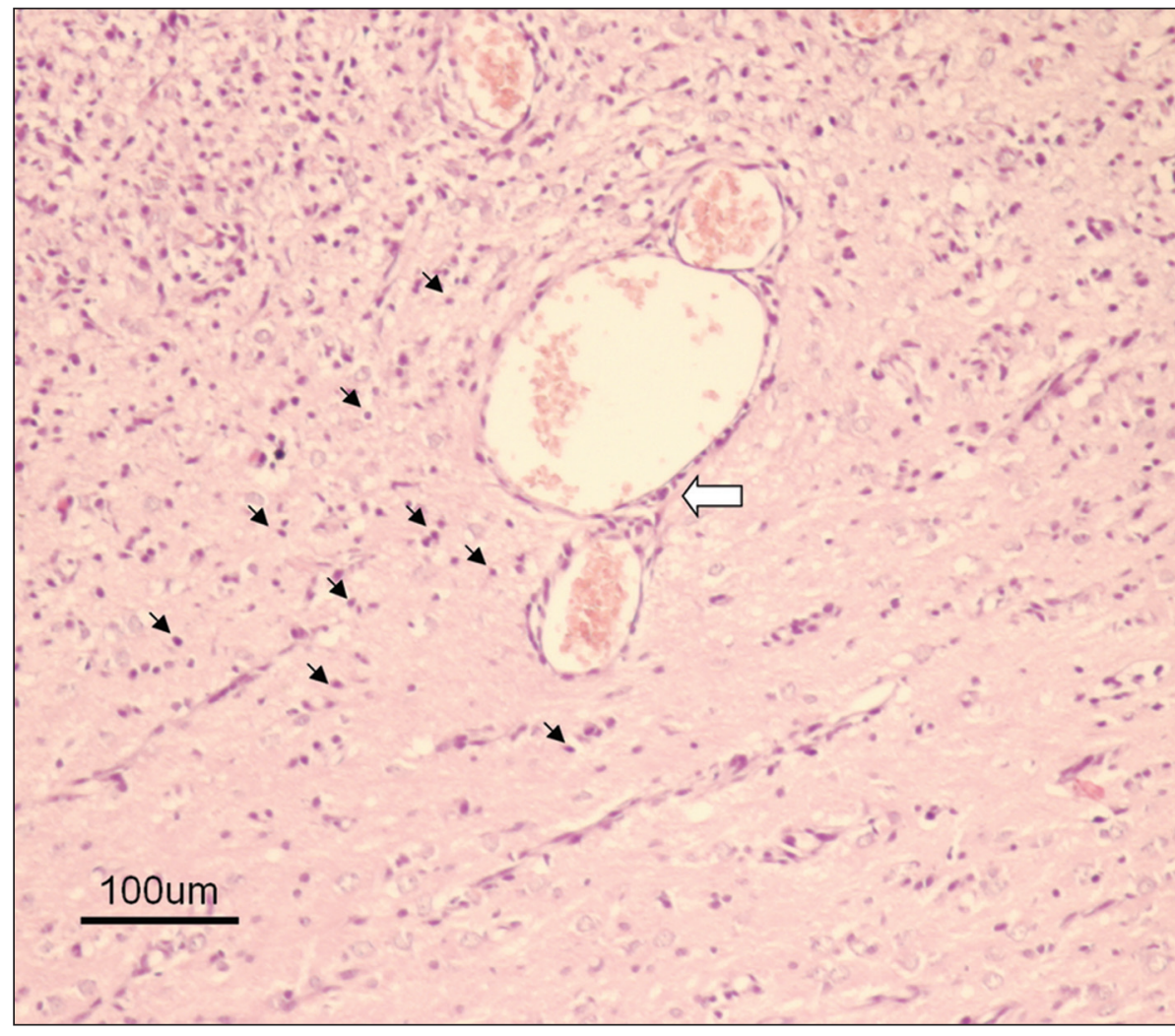

Figure. HE, 40x. Brain tumor transition area. No clear limit between tumor mass and neighboring brain parenchyma is observed. Numerous basophilic tumor cells clustering deeper in the brain parenchyma can be observed (arrows). The perivascular space is also infiltrated by tumor cells (arrowhead). 


\section{RESULTS}

No peri-operatory deaths occurred and none of the rats developed evident infectious complications, suggesting that basic asseptic care (asepsis of the skin and sterilization of surgical materials) was sufficient in handling athymic Rowett rats for the purposes stated.

Clinical assessment of the rats during the post-operative period revealed that the animals presented discrete periocular secretion build-up from the $17^{\text {th }}$ day after inoculation. No motor deficits were manifest.

Macroscopic analysis of the brain fragments demonstrated a tumor mass, which was visible to the naked eye in $100 \%$ of the rats. The lesion spread to the cortical surface at the inoculation point in all animals, displacing structures from the median line.

Analysis of the slides at lower magnification showed that the tumors took a predominantly spheroid configuration, located at the right frontal lobe, compressing and infiltrating the adjacent structures.

Higher magnification revealed that tumors were formed by polygonal-shaped cells with basophylic nuclei and eosinophyl cytoplasm. Hemorrhagic necrosis in small clusters was presented in all cases. The brain-tumor interface (Figure) demonstrated microscopic infiltration at the borders of the main lesion, where grouping of tumor cells were found beyond the edges of the main mass, even with some isolated tumor cells immersed in the cerebral parenchyma. This infiltration occurred not only in the cerebral parenchyma but also throughout the perivascular spaces. Infiltration of the leptomeningeal space was also observed. There was little inflammatory response adjacent to the tumor lesions.

\section{DISCUSSION}

Malignant brain gliomas, particularly glioblastomas have been the subject of intense study, mainly aiming at the discovery of more effective forms of treatment. The invasive pattern of gliomas and the migration of neoplastic cells along encephalic tracts and perivascular space renders such tumors very difficult to reproduce in experimental models.

Brain tumor cell culture models minimize the inflammatory and angiogenic responses which gliomas trigger in human brain tissue'. Animal tumor models based on implantation of established cell lines complement studies carried out in cell cultures, allowing the in vivo study of tumor responses to various therapeutic strategies. In addition, animal models allow comparison between groups of control and treated rats harboring tumors with more homogeneous size and location characteristics ${ }^{2}$. The ability to achieve accurate cell counts and homogeneously growing tumors was demonstrated by the two subcutaneously inoculated rats in our experiment, since upon infection of the same number of cells $\left(5 \times 10^{5}\right)$, they developed tumors of identical weight.

One of the most classical multiform glioblastoma models is based on injecting C6 cells. These cells have been used in experimental models with Sprague-Dawley, Long-Evans and Wistar rats, which are immunecompetent, therefore growth is under influence of the immune system. $\mathrm{C} 6$ cells growth is strongly influenced by the breed of rat in which they are inoculated. Tumors formed in the Sprague-Dawley and Long-Evans breeds are encapsulated and have well-defined limits, resembling metastatic lesions $^{3}$. Possibly the spheroid shape of the tumor masses represent more of a walling off and a degree of genetic incompatibility. However, when these cells are inoculated into the brain of Wistar rats, they exhibit invasive and pleomorphic GBM characteristics, including sites of necrosis and hemorrhage. Other aspects observed in Wistar rats include a high mitotic rate, cells forming palisades, and neovascularization ${ }^{4}$. These characteristics have led to the use of the $\mathrm{C} 6 /$ Wistar model in experiments due to its similarity to the human $\mathrm{GBM}^{5}$. Despite this similarity, other authors believe this model does not possess the same heterogeneity, immuno-histochemical characteristics or invasive capacity of the $\mathrm{GBM}^{6}$.

In vivo evidence shows that when C6 cells are inoculated into Wistar rats, they trigger a host-graft incompatibility immune response. When Wistar rats were simultaneously inoculated into the brain and subcutaneously into the flank, 100\% survival was observed, compared to $11 \%$ survival when inoculated only into the brain. It was concluded that $\mathrm{C} 6$ cells inoculated subcutaneously induce a significant immune response in Wistar rats, mimicking an anti-tumoral immune response while preventing this tumor from growing in brain tissue ${ }^{7}$. Interestingly, spontaneous regression after 70 days of stereotaxic inoculation of $\mathrm{C} 6$ cell spheroids into brains of immunocompetent and thymectomized Sprague-Dawley rats has reported ${ }^{8}$.

The exact origin of C6 cells remains unclear. Some authors have reported that these cells in fact originated from Wistar rats ${ }^{6}$, and were chemically induced in WistarFurth rats by exposure to N,N'-nitrosomethylureia'. Other authors have described $\mathrm{C} 6$ cells as compatible with BDIX ${ }^{10}$ and Sprague-Dawley rats" ${ }^{11}$. More recent molecular studies have isolated the $\mathrm{RT}^{\mathrm{u}}$ haplotype from $\mathrm{C} 6$ cells, indicating that it is consistent with the allogenicity in Wistar, BDIX, BDX and Sprague-Dawley rats ${ }^{12}$. Some authors have stated that $\mathrm{C} 6$ cells are not genetically compatible with any rat breed, and hence the immune response represents a limitation for the use of this model, specially if the comparative index is survival ${ }^{7,13}$. In fact, this C6 model is considered 
to be unsuitable for studying inflammatory changes observed in human gliomas ${ }^{13}$.

The use of an athymic model is helpful when using a completely dissimilar human cell line in an animal model, therefore, athymic rats are more typically used in studies involving xenografts. To use an athymic animal for developing an animal model with a $\mathrm{C} 6$ cell derived from rat, as presented here, downregulates the inflammatory response which may enhance the invasive characteristics of the tumor.

Our findings are compatible with a low immune response characterized by the near absence of inflammatory cells surrounding the tumor masses. The variable degree of an inflammatory response observed in other models is possibly evidence of immune incompatibility rather than the nature of a high grade glioma. The presence of an intact immune system is more likely to the forming of more encircled lesions such as those described for SpragueDawley and Long-Evans rat breeds. A morphometric study of $\mathrm{C} 6$ cell implants in rats has reported that the brain-tumor interface was well defined in immunocompetent rats, when compared to New Zealand athymic rats ${ }^{14}$.

In our model, we observed micro-infiltration of tumor cell clusters in the vicinity of the main tumor mass, and of more distal isolated tumor cells immersed in normal encephalic parenchyma (Figure). This degree of infiltration is superior to that usually observed in other C6 models.

Notwithstanding results observed of tumor invasive being attributed to the low immunological response of Rowett rats, other complex interactions amongst tumor cells and brain structures should also be taken into account.
In conclusion, $\mathrm{C} 6$ cells have high infiltrative characteristics when inoculated into athymic rats, resembling those observed in human GBM.

\section{REFERENCES}

1. Grobben B, DE Deyn PP, Slegers H. Rat C6 glioma as experimental model system for the study of glioblastoma growth and invasion. Cell Tissue Res 2002;310:257-270.

2. Nagano N, Sasaki H, Aoyagi M, et al. Invasion of experimental rat brain tumor: early morphological changes following microinjection of C6 glioma cells. Acta Neuropathol (Berl) 1993;86:117-125.

3. Farrell CL, Stewart PA, Del Maestro RF. A new glioma model in rat: the C6 spheroid implantation technique permeability and vascular characterization. J Neurooncol 1987;4:403-415.

4. Auer RN, Del Maestro RF, Anderson R. A simple and reproducible experimental in vivo glioma model. Can J Neurol Sci 1981;8:325-331.

5. Chicoine MR, Silbergeld DL. Invading C6 glioma cells maintaining tumorigenicity. J Neurosurg 1995;83:665-671.

6. San-Galli F, Vrignaud P, Robert J, Coindre JM, Cohadon F. Assessment of the experimental model of transplanted C6 glioblastoma in Wistar rats. J Neurooncol 1989;7:299-304.

7. Parsa AT, Chakrabarti I, Hurley PT, et al. Limitations of the C6/Wistar rat intracerebral glioma model: implications for evaluating immunotherapy. Neurosurgery 2000;47:993-999.

8. Vince GH, Bendszus M, Schweitzer T, et al. Spontaneous regression of experimental gliomas an immunohistochemical and MRI study of the C6 glioma spheroid implantation model. Exp Neurol 2004;190:478-485.

9. Benda P, Lightbody J, Sato G, et al. Differentiated rat glial cell strain in tissue culture. Science 1968;161:370-371.

10. Resnicoff M, Tjuvajev J, Rotman HL, et al. Regression of C6 rat brain tumors by cells expressing an antisense insulin-like growth factor I receptor RNA. J Exp Ther Oncol 1996;1:385-389.

11. Kruse CA, Molleston MC, Parks EP, et al. A rat glioma model, CNS-1, with invasive characteristics similar to those of human gliomas: a comparison to 9L gliosarcoma. J Neurooncol 1994;22:191-200.

12. Beutler AS, Banck MS, Wedekind D, et al. Tumor gene therapy made easy: allogeneic major histocompatibility complex in the C6 rat glioma model. Hum Gene Ther 1999;10:95-101.

13. Barth RF. Rat brain tumor models in experimental neuro-oncology: the 9L, C6,T9, F98, RG2 (D74), RT-2 and CNS-1 gliomas. J Neurooncol 1998; 36:91-102.

14. Saini M, Bellinzona M, Meyer F, Cali G, Samii M. Morphometrical characterization of two glioma models in the brain of immunocompetent and immunodeficient rats. J Neurooncol 1999;42:59-67. 